\title{
Implementing clonal forestry in the southeastern United States: SRIEG satellite workshop summary remarks
}

\author{
H.E. Stelzer and B. Goldfarb
}

\begin{abstract}
Fifty people from the forest genetics community participated in a 2-day workshop to identify and discuss issues concerning the implementation of clonal forestry in the southeastern United States. Consensus was that the most pressing issues fell into the general categories of biological and technological limitations, economics, and ecological and societal concerns. The key aspect of the biological barrier focused on the limitations imposed by the maturation of trees. Economic issues centered on the need for reliable estimates of costs and returns. Ecological and societal issues focused on the difficulty of quantifying ecological risk and the possibility that clonal forestry could be regulated based on perceived rather than actual risks. Discussions brought about the need for propagation scientists and forest geneticists to participate with other interested groups to determine the ecological and economic consequences of various deployment strategies. The information and confidence gained in these efforts should permit forest managers to move toward safe and effective implementation of clonal forestry.
\end{abstract}

Résumé : Un atelier de 2 jours qui reassembled 50 intervenants du domaine de la génétique forestière a permis d'identifier et de discuter des questions pertinentes à la mise en place de la foresterie clonale dans le sud-est des États-Unis. Le consensus était à l'effet que les questions les plus urgentes pouvaient être réparties en trois catégories, à savoir les contraintes biologiques et technologiques, les considérations économiques et les inquiétudes d'ordre écologique et social. Les contraintes imposées par la maturation des arbres constituaient le problème biologique le plus important. Au niveau économique, les besoins les plus pressants avaient trait à l'estimation fiable des coûts et des rendements. Du point de vue écologique et social, les principaux enjeux concernaient la difficulté de quantifier le risque écologique et la possibilité que la foresterie clonale soit réglementée sur la base d'une perception subjective plutôt que réelle des risques. Les discussions ont également permis de mettre en lumière le besoin, pour les généticiens forestiers et les physiologistes de la multiplication végétative, de participer avec les autres parties prenantes à la détermination des conséquences économiques et écologiques des stratégies de déploiement. Les informations et la confiance générées par ces efforts devraient permettre aux gestionnaires forestiers d'aller de l'avant de façon sécuritaire et efficace dans la mise en place de la foresterie clonale.

[Traduit par la Rédaction]

\section{Introduction}

Organizations around the world that are involved in the genetics, breeding, and improvement of forest trees have been interested in clonal forestry for many years. Clonal forestry has been implemented in some regions of the world (reviewed in Ahuja and Libby 1993) and has been discussed in several major international meetings (Libby 1974; Werner 1982; Hanover and Keathley 1988; Ahuja 1991; Lambeth et al.1994). There is keen interest in the potential gains that can result from clonal forestry, but there is also concern that the various biological barriers and public perception about genetic diversity of plant and animal populations will prevent its implementation.

Vegetative propagation procedures are currently being developed for some of the commercial forest tree species of the southeastern United States by scientists in various public and private wood resource organizations in the region. Some of the individuals who are involved in the development of these tech-

H.E. Stelzer. ${ }^{1}$ USDA Forest Service, Southern Research Station, Normal, AL 35762, U.S.A.

B. Goldfarb. Department of Forestry, North Carolina State University, P.O. Box 8002, Raleigh, NC 27695, U.S.A.

1 Author to whom all correspondence should be addressed. niques believed that it would be useful to identify current barriers to implementing clonal forestry and to discuss the future of this technology.

Fifty people from both public and private organizations participated in the 2-day workshop. The primary background of most participants was propagation science and (or) forest genetics, but field foresters as well as land management administrators were present. The workshop began with facilitated break-out sessions the first day in order to identify issues concerning the implementation of clonal forestry. The second day was used to compare and prioritize the issues identified by the individual groups, build consensus, and discuss future options.

The groups identified many issues ranging from detailed technological problems to vague uncertainties about public acceptance. However, by the end of the workshop, there was general agreement that the most pressing issues fell into the categories of (1) biological and technological barriers; (2) economics; and (3) ecological and societal concerns.

Participants also agreed that for discussion purposes, clonal forestry would be defined as the extensive deployment of well-characterized genotypes, as opposed to the bulking-up of heterogeneous mixtures (Libby and Ahuja 1993). In terms of species, much of the discussion concentrated on the southern pines, loblolly pine (Pinus taeda L.) and slash pine (Pinus 
elliottii Engelm.), because of their economic importance in the region. Based upon closing discussions, additional information was collected after the workshop and is included for elaboration.

\section{Biological and technological barriers}

Of all the potential issues, each break-out group ranked biological and technological barriers at or near the top of their list. If these barriers cannot be overcome, then economic, ecological, and sociopolitical issues become moot.

The group agreed that the key aspect of the biological barrier is maturation. The process of maturation describes the changes in woody plant developmental behavior that occur with increasing plant age (Greenwood and Hutchison 1993). Maturation can interfere with the implementation of clonal forestry in two ways: (1) Propagation ability tends to decline as the donor plant ages (reviewed in Hackett 1988). This decline applies to both macropropagation (e.g., rooted cuttings) and micropropagation (e.g., somatic embryogenesis) methodologies and is especially pronounced in many conifers, including pines. (2) Propagules derived from older donor plants may not have the same growth characteristics as their seedling counterparts (Foster et al.1987; Sweet 1973).

Because of these two effects of maturation, by the time an individual can be reliably selected for propagation, the ability to propagate may be lost or the performance of the resulting propagules diminished. Unless juvenility can be maintained long enough to adequately test individuals or restored after selection, the remaining option is to multiply high-value seed, such as progeny from superior, controlled crosses. Although by most definitions, this is not clonal forestry (Libby and Ahuja 1993), the strategy could be worthwhile, depending on the relative genetic values and costs of the seedlings and vegetative propagules (e.g., Arnold 1990). It does not, however, capture the potentially large amount of genetic gain that is available from selecting and mass producing the best individuals from the best families (e.g., Foster 1993).

The relationship between maturation and propagability has been recognized for many years (e.g., Gardner 1929), but efforts at propagating material from mature conifer trees have been met with limited success. Three basic strategies exist for evading or overcoming the problems maturation imposes on clonal forestry.

One strategy utilizes the maintenance of juvenility until clones can be tested, selected, and mass produced. In some cases, the juvenility of the donor plant material may be preserved by repeated hedging (Bolstad and Libby 1982; Copes 1983), by serial propagation (St. Clair et al. 1985), or by cryopreservation of embryogenic cultures (Talbert et al.1993).

A second strategy involves propagation from selected, mature trees. This requires restoration of juvenility or the recovery of juvenile parts from mature plants. Although this has been accomplished routinely in several hardwood species, for example, some Populus and Eucalyptus species that form stump sprouts after the aerial portion of the tree is removed (Zsuffa et al. 1993; Zobel 1993), rejuvenation or recovery of juvenility in most conifers has been less successful (reviewed in Bonga and von Aderkas 1993).

A third strategy would utilize early selection to identify superior individuals before maturation interferes with clonal deployment. In most species, reliable selections based on field tests are difficult to obtain at very early ages, although clonal replication removes some of the environmental variation (Frampton and Foster 1993). An alternative selection method may utilize genomic mapping for marker-assisted selection (e.g., Grattapaglia et al.1993). If superior genotypes can be accurately selected using molecular markers in a cost-effective manner, multiplication of clones could begin without waiting for longer term field tests. Some type of juvenility maintenance (using either hedged stock plants or serial propagation of rooted cuttings or culture maintenance or cryopreservation for somatic embryogenesis) would still be necessary to achieve sufficient numbers of individuals clones for large-scale plantings.

Finally, in addition to these strategies, a better understanding of the causes of maturation and how they affect woody plant development could lead to approaches not yet envisioned. Research efforts to understand the molecular basis for maturation are currently underway (e.g., Hutchison et al. 1990; Murray and Hackett 1991; Weir and Goldfarb 1993). Any or all of these strategies may eventually circumvent the current limitations that maturation imposes on clonal forestry today. The development of this technology for the commercial forest species of the southeastern United States will be dependent, at least in part, on the intensity of the research effort.

\section{Economics}

Assuming that the biological and technological barriers are overcome, other hurdles remain. If the clonal strategy does not make economic sense, it will never be used on a meaningful scale. Although geneticists and vegetative propagation scientists will probably not make the final decisions about whether to deploy clonal propagules, they can have input into the process in several ways.

First, researchers must develop good estimates of propagation costs so forest managers can compare the cost of vegetative propagules with that of their seedling counterparts. Seed orchard and nursery management practices for loblolly and slash pine have been refined to the extent that high-quality seedlings can be reliably produced at low cost. Current openmarket prices for second-generation, improved 1-0 planting stock average \$42 (U.S.) per thousand seedlings (J. McRae, private communication). However, systems for the vegetative propagation of southeastern U.S. forest tree species are not well developed. Therefore, rooted cuttings will undoubtedly be more costly than bare-root seedlings.

While estimating the costs for producing large numbers of rooted cuttings will require more specific information about systems than is available at present, one can estimate the range that could be spent on vegetative propagation under different sets of assumptions. Current pulpwood prices in the southeastern United States range from $\$ 25 /$ cord in noncompetitive markets to as high as $\$ 50 /$ cord in areas where several paper mills are competing for the same wood fiber (J. Vardaman, private communication). Planting densities can be as low as 959 trees/ha and up to 1498 trees/ha, or even higher on some industrial lands. The discount rate that forest product companies across the region use to analyze investment opportunities varies, but the average range is from $5 \%$ to $10 \%$. Incremental genetic gain estimates attributed to vegetative propagation range from $10 \%$ (Foster et al. 1981) to as high as 25\% (Bentzer 1993). With the final assumptions of a 25-year rotation and an unimproved 
Table 1. Present value of $10 \%, 15 \%$, and $25 \%$ genetic gains from vegetative propagation.

\begin{tabular}{|c|c|c|c|c|c|c|c|}
\hline \multirow{2}{*}{$\begin{array}{l}\text { Stumpage price } \\
\text { (\$US/cord) }\end{array}$} & \multirow{2}{*}{$\begin{array}{l}\text { Planting density } \\
\text { (trees/ha) }\end{array}$} & \multicolumn{3}{|c|}{$10 \%$ discount rate } & \multicolumn{3}{|c|}{$5 \%$ discount rate } \\
\hline & & $10 \%$ & $15 \%$ & $25 \%$ & $10 \%$ & $15 \%$ & $25 \%$ \\
\hline \multirow[t]{3}{*}{25} & 1498 & 11 & 17 & 29 & 40 & 59 & 99 \\
\hline & 1183 & 5 & 22 & 36 & 50 & 75 & 125 \\
\hline & 959 & 18 & 27 & 45 & 62 & 93 & 154 \\
\hline \multirow[t]{3}{*}{50} & 1498 & 23 & 34 & 57 & 79 & 119 & 198 \\
\hline & 1183 & 29 & 43 & 72 & 100 & 150 & 250 \\
\hline & 959 & 36 & 54 & 89 & 124 & 185 & 309 \\
\hline
\end{tabular}

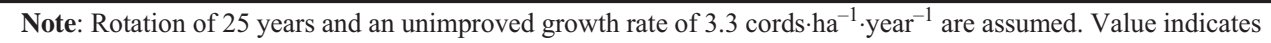
how much a person could spend per thousand propagules to realize the indicated genetic gain and realize a given rate of return on the investment over and above inflation. Values have been rounded to the nearest U.S. dollar.

growth rate of 3.3 cords $\cdot$ ha $^{-1} \cdot$ year $^{-1}$, the present value of vegetative propagules under different scenarios are found in Table 1.

If production costs for rooted cuttings are three times that for seedlings, as is the case for Norway spruce (Picea abies (L.) Karst.) (Kleinschmit and Schmidt 1977), then the present value in Table 1 must exceed $\$ 126$ to recoup this additional propagation cost. Present values exceeding \$126 require higher stumpage prices to make rooted cuttings profitable, especially in the case of lower genetic gains or higher discount rates. Unless the differential between seedlings and rooted cuttings is less than $\$ 126$, vegetative propagules will probably be used to regenerate only high site index lands or for rotation lengths that will produce larger, more valuable sawtimber trees.

Second, to balance the added cost of propagules, researchers must be prepared to deliver greater returns in terms of more volume, better quality, reduced handling costs, and (or) greater processing efficiency. Gains in volume and wood quality will result from the successful integration of breeding and propagation programs. One possible strategy would be to use positive assortative mating as a tool to develop a nucleus of elite individuals (Cotterill 1984). This process increases the frequency of extreme genotypes as compared with a random mating population. The progeny of the elite nucleus would then be vegetatively propagated and clones for operational production could be chosen using a type of mass selection (Foster 1993).

A critical factor in developing accurate estimates of economic returns will be to establish test plantings. The tests should be designed to document yield at the stand level and test for the efficiencies of handling more uniform product material in the field and at the mill. These yield and revenue figures could then be combined with cost figures from pilot-scale propagation operations to give managers meaningful information on which to base decisions.

Finally, geneticists and propagation scientists should use this cost and revenue data to educate decision makers about appropriate strategies. Because of the higher establishment cost associated with vegetative propagules, and the long rotations associated with forest plantations, it will be crucial to reinforce the forest manager's need to examine the eventual return on investment as well as the short-term expense. This argument is strongly reminiscent of debates that occurred across the southeastern United States in the past over plantation establishment versus natural regeneration and whether to invest in tree improvement activities. It should be noted that both prac- tices are now commonly employed in the region, despite their higher initial cost.

\section{Ecological and societal concerns}

There was widespread agreement among workshop participants that there is increasing public concern about the manipulation of nature. Planting clonal forests appears to be more of a deviation from the public perception of natural forests than establishing seedling forests (Kleinschmit et al.1993), just as establishing plantations may strike some individuals as more artificial than natural regeneration, and doing any type of harvest and regeneration seems more artificial than leaving forests untouched. Thus, it is clear that the way the public may perceive and react to the possibility of clonal forestry is to some extent inseparable from the entire issue of whether trees should be grown solely for fiber in intensively managed plantations. The end result of such debate could result in legislation that would restrict, or even prohibit, the implementation of clonal forestry in the southeastern United States, as has occurred elsewhere (B. McCutchan, C. Talbert, T. White, and F. Bridgwater ${ }^{2}$ ).

Within this context, many participants agreed that it is important to point out that by increasing productivity on certain designated lands, foresters will be able to meet society's wood resource demands on a smaller land base. This will, in turn, provide more land for wildlife habitat, human recreation, and water quality improvement zones. Forest management of the future could include a true fiber farm component and clonal forestry could make an important contribution to enhanced plantation productivity.

In the course of the debate, it will be important to determine the actual versus perceived risks associated with clonal forestry. The severe impact of the Marsoninna brunea, a fungus causing browning of leaves and shoots, on poplar (Populus spp.) in Italy (Heybroek 1978) and the large-scale effects of poplar leaf rust (Melampsora spp.) on Australian poplar stands (Zsuffa et al.1993) are two examples of the reality of actual risks in the presence of genetic uniformity. However, it must be pointed out that these failures were a result of very few

\footnotetext{
2 B. McCutchan, C. Talbert, T. White, and F. Bridgwater.

Regulations and trends worldwide in genetic deployment of commercial forest plantations. Presentation at the Southern Regional Information Exchange Group Meeting on Genetic Diversity in Commercial Forest Tree Plantations, 18-20 July 1994, Clemson University, Clemson, S.C.
} 
genotypes in the breeding population and large, monoclonal plantations. We hope today's forest geneticists have learned from their predecessors' mistakes.

Risk assessment models (Roberds and Bashir 1996) can provide the forest manager with important information for minimizing the effects of catastrophic events such as those mentioned above. Some of the basic biological parameters included in these models are (1) the number of distinct tree genotypes making up the plantation, (2) the proportion of each genotype, (3) the spatial arrangement of those genotypes, (4) mode of gene action for susceptibility, (5) the response of each tree genotype to the causal agent's attack, and (6) the severity of attack and history of previous attacks by the causal agent. Social, or human, parameters include the minimum unacceptable mortality rate due to the destructive agent and the forest manager's maximum acceptable risk of plantation failure. However, the conclusions are only as good as the initial assumptions, and unfortunately, accurately predicting sporadic, catastrophic events is problematic. Further, some of the critical parameters, such as the frequency of susceptible genotypes to an unidentified stress, are largely unknown.

Perceived risks are based more on fear than on fact. It is safe to assume that different interest groups will have varying views on what are those perceived risks. Forest pathologists and entomologists might be concerned about the risk of the trees' susceptibility to some yet unknown pest being linked to those traits that are being selected for in the breeding program. Private conservation groups might point to the risk of reduced biological species diversity as a result of increasing the genetic uniformity of a dominant organism in the landscape (Friedman and Foster 1997). Industrial and nonindustrial private landowners might fear the risk of not being able to plant genetically improved clonal material because unfounded concerns regarding genetic diversity might lead to regulations restricting the use of this new material (Lambeth and McCullough 1997).

A useful concept that arose from discussions was that there are actually several distinct constituencies on this issue, and that to move forward, clonal propagation scientists must gain some measure of confidence from each group. Some of the constituencies that came to mind were (1) plant geneticists and breeders; (2) scientists from other disciplines such as forest ecology, pathology, and entomology; (3) industrial and nonindustrial private landowners; (4) public landowners; (5) private conservation groups; and (6) the general public.

While no concrete strategy was developed on how to work with all of these groups, a number of useful ideas were presented. First and foremost, individuals in each group must be treated as true partners, rather than trying to convince them that geneticists and propagators have all the answers. This mutual ownership could be fostered by seeking input from these groups during the planning phase of clonal test establishment. Identifying their concerns and what they would like to see monitored in these tests could avoid future misunderstandings. These lines of communication could be enhanced further by developing fact sheets and position papers that are distributed to both scientific and less technical audiences.

The experience in a number of European countries suggests that this issue cannot be ignored. If a general consensus cannot be reached about how to implement clonal forestry in an ecologically as well as economically responsible manner, then these practices will be regulated by legislative bodies that are responding to public pressure more than to scientific realities.

\section{Future prospects}

It was quite clear from the workshop that issues in any one broad category, as defined in this summary, could not be suitably addressed without considering the effects of issues in the other categories. For example, one issue raised was the need for better information on how to deploy clones in plantations. How many clones should be planted? How many hectares should be planted with a given clone? What will the spatial arrangement of these clones look like? The answers to these questions will be influenced by issues in each of the three categories.

The area to be planted with propagules from any one clone is currently limited by biological factors for the southern pines. The choice of how many clones, which clones, and where to plant them will depend on the organization's economic strategy. For example, the best clones might be reserved for highly productive sites that are close to the processing plant. Likewise, the number and arrangement of clones will have to be based on sound ecological principles to minimize risk. On this crucial point, economic risks closely parallel ecological risks. Widespread plantation failure achieves no one's objectives.

As this technology emerges, forest scientists must be aware that they are not working in a vacuum. In fact, whether or not the technology is ever implemented may depend more on how well they communicate, educate, and team with other groups than on how well they conduct experiments. If the vast potential of clonal forestry is to be realized, scientists who developed the technology, and wish to use it, must remain active participants in dialogue to insure its safe and effective implementation, and its acceptance by the public.

\section{References}

Ahuja, M.R. 1991. Woody plant biotechnology. Plenum Press, New York.

Ahuja, M.R., and Libby, W.J. 1993. Clonal forestry II. Conservation and application. Springer-Verlag, Berlin.

Arnold, R.J. 1990. Control pollinated radiata pine seed-a comparison of seedling and cutting options for large-scale deployment. N.Z. J. For. 35(3): 12-17.

Bentzer, B.G. 1993. Strategies for clonal forestry with Norway spruce. In Clonal forestry II. Conservation and application. Edited by M.R. Ahuja and W.J. Libby. Springer-Verlag, Berlin. pp. 120-138.

Bolstad, P.V., and Libby, W.J. 1982. Comparison of radiata pine cuttings of hedge and tree-form origin after seven growing seasons. Silvae Genet. 31: 9-13.

Bonga, J.M., and von Aderkas, P. 1993. Rejuvenation of tissues from mature conifers and its implications for propagation in vitro. In Clonal forestry I. Genetics and biotechnology. Edited by M.R. Ahuja and W.J. Libby. Springer-Verlag, Berlin. pp. 182-199.

Copes, D.J. 1983. Effects of annual crown pruning and serial propagation on rooting of stem cuttings from Douglas-fir. Can. J. For. Res. 13: 419-424.

Cotterill, P.P. 1984. A plan for breeding radiata pine. Silvae Genet. 33: 84-90.

Foster, G.S. 1993. Selection and breeding extreme genotypes. In Clonal forestry I. Genetics and biotechnology. Edited by M.R. Ahuja and W.J. Libby. Springer-Verlag, Berlin. pp. 50-67.

Foster, G.S., Lambeth, C.C., and Greenwood, M.S. 1987. Growth of loblolly pine rooted cuttings compared with seedlings. Can. J. For. Res. 17: 157-164. 
Friedman, S.T., and Foster, G.S. 1997. Forest genetics on federal lands in the United States: public concerns and policy responses. Can. J. For. Res. 27: 401-408.

Gardner, F.E. 1929. The relationship between tree age and the rooting of cuttings. Proc. Am. Soc Hortic. Sci. 26: 101-104.

Grattapaglia, D., Chaparro, J., Wilcox, P., McCord, S., Crane, B., Amerson, H., Werner, D., Liu, B.H., O'Malley, D., Whetten, R., McKeand, S., Goldfarb, B., Greenwood, M., Kuhlman, G., Bridgewater, F., and Sederoff, R. 1993. Application of genetic markers to tree breeding. In Proceedings of the 22nd Southern Forest Tree Improvement Conference, 14-17 June 1993, Atlanta, Ga. Edited by CW. Lantz and D.J. Moorhead. The National Technical Information Service, Springfield, Va. pp. 452-463.

Greenwood, M.S., and Hutchison, K.W. 1993. Maturation as a developmental process. In Clonal forestry I. Genetics and biotechnology. Edited by M.R. Ahuja and W.J. Libby. Springer-Verlag, Berlin. pp. 14-23.

Hackett, W.P. 1988. Donor plant maturation and adventitious root formation. In Adventitious root formation in cuttings. Edited by T.D. Davis, B.E. Hassig, and N. Sankhla. Dioscorides Press, Portland, Oreg. pp. 11-28.

Hanover, J., and Keathley, D. 1988. Genetic manipulation of woody plants. Plenum Press, New York.

Heybroek, M.M. 1978. Primary considerations: multiplication and genetic diversity. Unasylva, 30: 27-33.

Hutchison, K.W., Sherman, C.D., Weber, J., Smith, S.S., Singer, P.B., and Greenwood, M.S. 1990. Maturation in larch. II. Effects of age on photosynthesis and gene expression in developing foliage. Plant Physiol. 94: 1308-1315.

Kleinschmit, J., and Schmidt, J. 1977. Experiences with Picea abies cuttings propagation in Germany and problems connected with large scale application. Silvae Genet. 26: 197-203.

Kleinschmit, J., Khurana, D.K., Gerhold, H.D., and Libby, W.J. 1993. Past, present, and anticipated applications of clonal forestry. In Clonal forestry II. Conservation and application. Edited by M.R. Ahuja and W.J. Libby. Springer-Verlag, Berlin. pp. 9-41.

Lambeth, C.C., and McCullough, R.B. 1997. Genetic diversity in managed loblolly pine forests in the southeastern United States: perspective of the private industrial forest land owner. Can. J. For. Res. 27: 409-414.

Lambeth, C.C., Ritchie, G.A., and Stanton, B. 1994. Applied vegeta- tive propagation programs in forestry. In Applications of vegetative propagation in forestry. Edited by G.S. Foster and A.M. Diner. U.S. For. Serv. South. For. Exp. Stn. Gen. Tech. Rep. SO-108. pp. 123-136.

Libby, W.J. 1974. A summary statement on the 1973 vegetative propagation meeting in Rapture, New Zealand. N.Z .J. For. Sci. 4(2): 454-458.

Libby, W.J., and Ahuja, M.R. 1993. Clonal forestry. In Clonal forestry II. Conservation and application. Edited by M.R. Ahuja and W.J. Libby. Springer-Verlag, Berlin. pp. 1-8.

Murray, J.R., and Hackett, W.P. 1991. Dihydroflavonol reductase activity in relation to differential anthocyanin accumulation in juvenile and mature phase Hedera helix L. Plant Physiol. 97: 343-351.

Roberds, J.H., and Bashir, J.W. 1997. Risk analyses in clonal forestry. Can. J. For. Res. 27: 425-432.

St. Clair, J.B., Kleinschmidt, J., and Svolba, J. 1985. Juvenility and serial vegetative propagation of Norway spruce clones (Picea abies Karst.). Silvae Genet. 34: 42-48.

Sweet, G.B. 1973. The effect of maturation on the growth and form of vegetative propagles of radiata pine. N.Z. J. For. Sci. 3: 191-210.

Weir, R.J., and Goldfarb, B. 1993. Loblolly and slash pine rooted cutting research at N.C. State University. In Proceedings of the 22nd Southern Forest Tree Improvement Conference, 14-17 June 1993, Atlanta, Ga. Edited by CW. Lantz and D.J. Moorhead. The National Technical Information Service, Springfield, Va. pp. 434-446.

Werner, M. 1982. Vegetative propagation and tree breeding strategy: synthesis of discussions in session 2. In Proceedings of the IUFRO Joint Meeting of Working Parties on Genetics About Breeding Strategies Including Multiclonal Varieties. 6-10 Sept. 1982, Sensenstein, Germany. Lower Saxony Forest Research Institute, Department of Forest Tree Breeding, D-3513 Staufenberg-Escherode, Federal Republic of Germany. pp. 115-118.

Zobel, B. 1993. Clonal forestry in the eucalypts. In Clonal forestry II. Conservation and application. Edited by M.R. Ahuja and W.J. Libby. Springer-Verlag, Berlin. pp. 139-148.

Zsuffa, L., Sennerby-Forsse, L., Weisgerber, H., and Hall, R.B. 1993. Strategies for clonal forestry with poplars, aspens, and willows. In Clonal forestry II. Conservation and application. Edited by M.R. Ahuja and W.J. Libby. Springer-Verlag, Berlin. pp. 91-119. 